\title{
THE ASSESSMENT OF COUNCIL-EXECUTIVE ROLES AND STYLES IN THE ETHIOPIAN URBAN CENTRES
}

https://doi.org/10.47743/jopafl-2021-20-01

\author{
Jemal ABAGISSA \\ Addis Ababa University \\ Department of Public Administration and Development Management \\ jemal.abagissa@aau.edu.et
}

\begin{abstract}
Urban governments are composed of lawmakers and law implementers just like most national governments. The lawmakers are councilors elected by the residents through regular local elections whereas those who implement policies, laws and ordinances are mostly selected. These urban government organs exist in different forms based on local and national political and administrative structures. There are three most common urban government models practiced in many places namely; council- mayor model, commission model and council-manager model. In some places, a variant of one model can be mixed to the other to fit local circumstances. The purpose of this study is to assess and identify the typologies and roles of urban government models in Ethiopia. To this effect, various secondary data sources were consulted. A review of proclamations and legislations issued by various Regional States in Ethiopia show both the council- mayor and the council-manager model are adopted in different urban centres in different regional governments including the city of Addis Ababa. In the council-mayor model, a weak mayor type is exercised because urban councils rely on committees established to implement and oversee councilors' decisions. The council-manager model has been adopted with amended legislations in the later years of the urban reform. However, the practice of the council-manager model in the Amhara, Oromia and Addis Ababa City does not stand the test of council-manager model requirements identified in the literature. This is because the managers are not politically neutral and no open vacancies are announced to select managers.
\end{abstract}

Keyterms: council, executive, council-mayor, council-manager, urban, Ethiopia

\section{Introduction}

Urban government systems are characterized by a dual power structure in which two bodies play prominent roles: the mayor and a directly elected popular assembly (referred to as municipal council). Even though the models of urban government in the world differ in many important respects, in all systems the council is conceived as a crucial channel in the communication between citizens and their local governments. The distinction between the roles of elected representatives (councilors) and executives is very important in urban government. Councilors are elected by the public to serve for a period of election terms. They are elected onto a local council and only keep their positions if they are re-elected. As lawmakers, councilors give political direction and leadership in the municipalities. A much larger group of professional public servants and senior executives support this small group of elected officials in translating its laws and programs in to outcomes.

While mayors and city managers often develop and propose policies, their basic authority is to carry out the council's directives and to implement the policy adopted by councils. To this effect, municipalities employ large number of staff to look after roads, sewers, fire, recycling and garbage programs, parking enforcement, city recreation, public health services and law enforcement. The success of a municipality is therefore determined 
by the quality of these branches namely mayor and councilors, and by the quality of the public servants.

Various typologies of urban government systems and structures have been addressed in much local government literature based on theoretical and empirical analysis. Some countries emphasize strong political leadership; others prefer power sharing and the involvement of laypersons in the executive and legislative functions of government, while still others adopt weak executive styles with strong urban councils (C Collinge,1997).

The responsibilities of urban governments differ across countries and cities, with structure and organization influenced by the historical, social and political context. National governments allocate responsibilities to the various levels of government, designating territorial jurisdictions, establishing electoral arrangements and designing internal management structures. Therefore, a clear understanding of roles, styles and relationships between the major local government branches is important both theoretically and empirically to know how relationships between those organs takes place in specific political and administrative environments.

Most of the studies done so far focus on urbanization, urban services and infrastructure, unemployment and related subjects. However, one of the important subjects in public administration, the types and roles of councilors and the executives, is given little attention in the urban discourse.

The researcher is motivated by the fact that the nature and typologies of councilexecutive relationship in Ethiopia is not explored so far despite the effect of these relationships on the functioning of the cities. There is little research, which illuminates this relationship, and certainly little is done in Ethiopia. The purpose of this paper is to identify and assess council-executive types, roles and relationships in Ethiopian urban centres.

\section{Methodology}

This study was based on desk review of existing urban government models in Ethiopia in relation to the theoretical literature on urban government models. A theoretical review of the existing literature has been done and secondary data sources have been used to analyze the existing situation of urban management models in Ethiopia. Government policy, legal documents at both local and national levels have been reviewed to identify the typologies of urban governments. The sources of the secondary data include Federal constitution of Ethiopia and proclamations issued by various regional governments regarding urban government roles and structures. Based on the collected data and review of related literatures, interpretation, analysis and conclusion were drawn.

\section{Literature Review}

Administrative structure of local government is the framework within which local public policies and programs are determined and implemented. The administrative structure of an urban government not only determines the relationship between government organs but also its character and strength. Therefore, discussions of municipal government are usually about the activities of the mayor and councilors. After all, councils (elected officials) make the important policy decisions and ordinances. The mayor is at the apex of executive wing of the urban government which executes councilors' laws and policies. 
This small group of elected officials is supported by a much larger group of professional public servants who advise the mayor and council and engage in the mundane tasks of building and maintaining roads, ensuring a safe and secure water supply and a range of other urban amenities (Thornhill, C. 2005).

Despite the universality of legislative and executive organ of local governments around the world, the way they are structured and the roles each play is widely variable. It is variable not only between countries but also with in a country. This shows that the structure and roles of these organs of urban government are affected by various factors including political regimes, administrative preferences and the level of urban status in the national setting. The types of localities, size, density and services provided also affect the selection of forms of urban government.

\section{The Councils and Executives in Urban Centers}

In all the political systems, there are two important arms of government - the Legislature and the Executive. These are respectively the rule making and rule application organs of government (Thornhill, C. (2005). In the subsequent sub-section, these organs are briefly presented which will be followed by the relationships of the two organs of urban government.

\section{The Urban Council}

The municipal council plays several roles in the light of the external and internal context. On the one hand, referring to the external settings, the municipal council conducts the business of representation and act as an advocate and defender of citizens' interests. It is also responsible for formulation of local policies and practices, which are perceived as meeting socio-economic needs and delivering welfare. Paradza, Mokwena and Richards (2010) assert that councillors are the intermediaries between the municipality and the residents. In order to perform their roles, they have to interact with both residents and municipal officials. Municipal councillors are required to perform an oversight role of the municipality functions, programmes and the management of the administration. In the process of governance, they examine and discuss bills on various subjects that are brought before them. They can repeal, alter or add to the provisions of existing laws and make them applicable to changing conditions depending on the extent of power vested in them. On the other hand, the executive arm of government implement laws and ordinances that is, their major functions include that of law enforcement, the execution of policy and advisory roles on to the council. The local council that represents the citizens is expected to oversee executive policy implementation and service delivery and hold the local bureaucracy accountable for its performance

\section{The Executive Organ}

The concept of "the executive" is multi-faceted. At the most general level the executive function implies organizational authority: the direction of the municipal bureaucracy and service delivery institutions, the implementation of policies decided by the city council, and horizontal coordination (between departments). It also involves vertical coordination, i.e. acting as a linkage between the political and administrative level. Several more specific indicators have been introduced to cover central aspects of the executive function like control over budget formulation, oversight of budget 
implementation, hiring of staff, appointment of members of boards and commissions, ex officio membership on boards and committees

The Mayor as Chief Executive Officer

Executives make decisions everyday as part of their responsibilities to solve different problems of the organization strategies, structures, performance and many other issues. The mayor is variously described as "the chief officer," "the chief executive officer" or "the head of council". As the focal point in the local government process, the chief executive officer works closely with the council in the development of policy and directs staff in implementing policies (Humes\& Martin, 1969). The chief executive officer does not only take the leading part in formulating ideas, but also has an important expository role as the mobilizer of support for proposals. As the focus for the development of the proposals, he/she is expected by the council and the public to ensure their favorable consideration. The effective chief executive officer, either directly or indirectly, must not only build up enough support in council so that his/her proposals are adopted but he/she must also develop sufficient support within the electorate so that he/she and those council members who support his/her proposals are reelected to office (Ridley, 1959).

\section{The Executive Committee}

Due to the limited size of the council, it is difficult for the council as single structure to perform all the actions necessary within urban government. Therefore, certain supportive structures are created to assist the council in the execution of its tasks. One of these structures is the Executive Committee. The Executive Committee is an executive organ of a unit of local government that has the central overall task of directing, initiating and coordinating all or most of the activities of the urban centre. The executive committee is a plural executive organ composed of elected persons. It is responsible to the council and generally has few members. The executive or mayoral committee is commonly made up of councilors with specific portfolios which match the departments within the municipal administration, for example, health. The executive and the mayor oversee the work of the department heads, managers and staff (John P. PelisseroLoyola, 1997). City councils' use of committees is likely to vary with council size. Larger cities tend to have more council members and thus a greater need to accommodate a variety of individual and collective policy goals. Larger cities also are more likely to use committees for policy-making because they are expected to face greater demands from the public to address a broader range of issues than those faced by smaller cities (DeSantis 1987, Svara199).

\section{The Department Heads}

Among the most important positions on the staff are the heads of departments. Not only do department heads direct the work of the employees in their respective departments, they also play an important part in the preparation and in the actual making of the decisions affecting their departments (Humes\& Martin, 1969: 155-156). The department heads work in close conjunction not only with the representative organs in carrying out the decisions of the councils and the executive committees but also prepare the papers which lay the groundwork for the decisions made by these bodies. In most cases, the department heads report directly to the chief executive officer. Departmental heads have responsibility for a specific discipline within a local authority. For example, the department head of finance takes responsibility for the administration of finances and its implementation thereof. 
Likewise, a city might have a security department to deal with all matters affecting public security and a fire department to handle all firefighting, or it might have a public safety department dealing with all police and fire matters. Other departments may be organized to handle such activities as public works, water supply, education and health. Such departments are also known as line departments (Bromage, 1957). Departments are also organized to deal with matters affecting one or more aspects of the management of local government activities. There may be, for instance, a legal department, a records department, a personnel, or a building and supply department. These non-line departments which deal with matters that affect all local activities are called auxiliary or staff departments.

\section{Council-Executive Typologies}

The preceding section highlighted the major organs of local governments and their roles. In the subsequent section, the type of council-executive relationships will be discussed in a detailed way. A city government usually is organized in one of three ways. Depending on its charter, central or state government constitutions, a city may have a mayor-council government (with either weak or strong mayor), a commission government, or a council-manager government (Marger and Bertrana, 2005).

\section{The Council Mayor Model}

The oldest and most common form of city government is the mayor-council government. The council-mayor model is a municipal government in which the executive power belongs either to the council or to the mayor depending on the preference of local government. In this kind of government, the city council is the legislative body, while the mayor is the city's chief executive organ. In this model, a city may be divided into several districts, often called wards. The people of each ward elect one person to represent them in a city council. In some cities, several council members at large are elected by all the voters in the city, rather than just the voters of one ward (Mouritzen, Poul Erik, James H. Svara (2002). Council Mayor Model is characterized by a separation of powers in which the mayor serves as chief executive while the council fulfills the role of the legislative arm of government. Hence, formally, the mayor serves as the chairman/president of the council and chief executive officer of the city administration. The main function of the council is to make laws and approve the budget (Snider, 1950). Depending on local preferences there are two variants of council-mayor models namely weak- mayor-council model and strongmayor-council model.

\section{Weak mayor model}

In a weak mayor-council form of government, the mayor is mainly a ceremonial figure. The council is not only the policymaking body, but also provides a committee form of administrative leadership and exercises the powers of appointment and removal of agency/department heads and budget preparation. In this form of government, the council possesses both legislative and executive authority. The council may appoint officials and approves mayoral nominations. The council also exercises primary control over the municipal budget (Jacobowitz And Gubits, Llp(2006). Typically, Weak-Mayors are not separately elected by the voters. Separate elections for any given office usually signal that the office holder will function differently from other elected officials; that is, his or her 
duties somehow are unique in the government and a separate election for the office is justified. Since Weak-Mayors are not distinguishable for the most part from other elected officials, the need to elect them separately does not exist. For this reason, a typical WeakMayor charter requires elected officials to decide among themselves which of them will serve as mayor. In many cities where this model is applied, the primary role of the mayor is to take care of ceremonial activities. The mayor has only a little power. For example, the mayor cannot appoint people to the council or develop the city's budget. Nor can she/he veto the city council's decisions. Besides, the mayor has a limited power in the appointment of heads of departments in the municipality and has to get the approval of the council to do this. The biggest advantage of this model is that the city is not controlled by one single person. Thus, the city is less subject to some individual clumsy mistakes and corruption is less likely to harm the city.

\section{Strong Mayor Model}

Many city governments using the mayor-council form of government have adopted a strong-mayor type of city government. Under the strong mayor model, the mayor is the strong chief executive officer and has the primary responsibility for running the city's government. For example, the mayor appoints most of the city officials. He or she usually prepares the city budget. In some cities, the mayor can also veto ordinances passed by the city council (National Civic League, 1996). Hence, the Mayor-Council form invests most or all executive powers in the mayor and thus provides for clear leadership in city government. Due to the formal powers built into the system, the mayor has the ability to set the agenda and deliver on it. This power means that voters can expect that promised projects will not get buried in the legislative process, especially when the mayor controls the budget and has a veto. In other words, a strong mayor may lead to a better correlation between mayoral proposals and outcomes. Furthermore, since city departments are directly responsible to the mayor, coordination problems are generally reduced. In short, the major benefit of this system is that more functions can be accomplished more quickly. This shows that this model emerged to solve weak mayor model drawbacks.

The mayor and a much smaller body of councilors are the only elected officials and the separation of executive and legislative is much more apparent than in the Weak Mayor variant. In its most general form, the Strong Mayor system usually assigns the mayor a combination of:

- control over the appointment and removal of department heads

- $\quad$ broad mayoral veto power

- the preparation and execution of the budget

In addition to the general formal powers, the mayor also develops new policy initiatives, sets the political agenda, and in all other respects "drives" the city government. The council in this arrangement is rather weak. Its responsibilities include the approval of the budget, the passing of resolutions with legislation, auditing the performance of the mayor and bureaucratic structure, and the adoption of general policy positions (ICMA, 1999). 


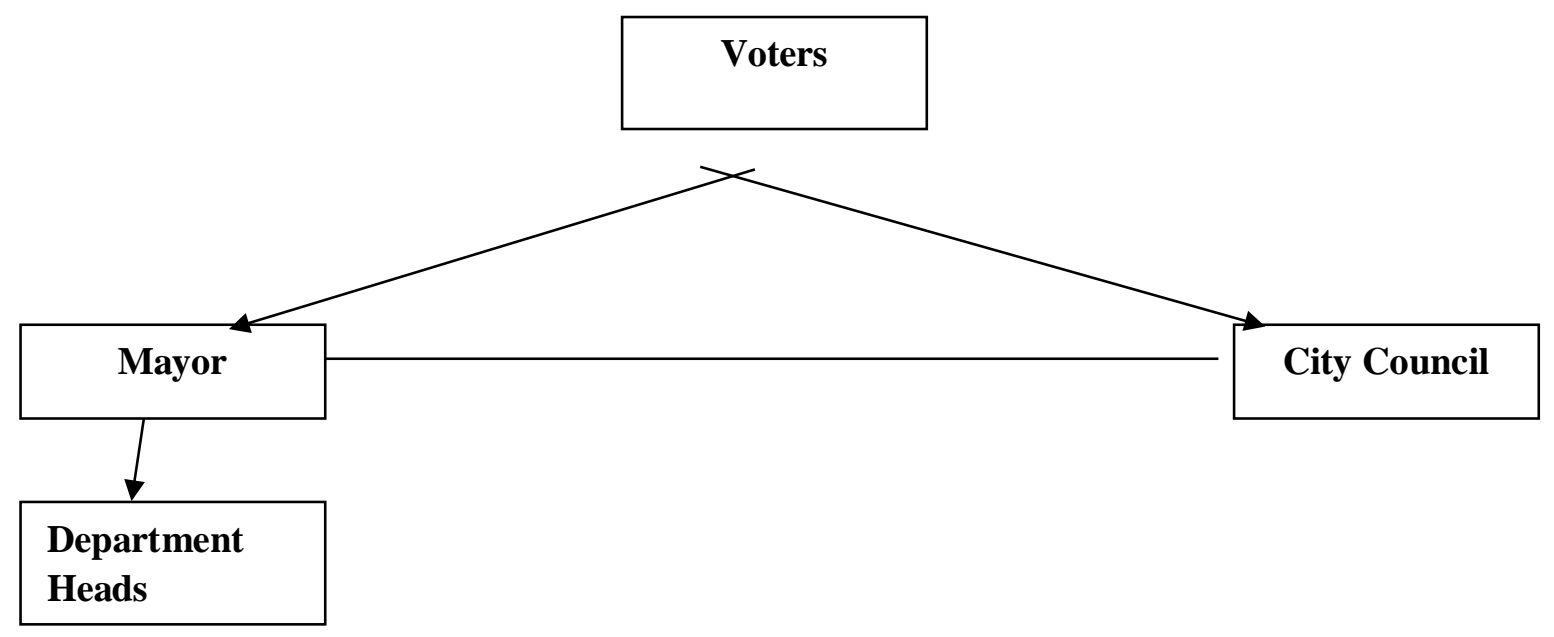

Figure 1 Strong mayor form model

The choice of strong mayor model has been influenced by the political changes in many areas where the model has been adopted. In terms of rhetoric, the 1990's were dominated by the rising popularity of New Public Management (NPM). Although the NPM ideology is a multifaceted and not necessarily consistent set of ideas, most of its advocates would probably agree on the need to strengthen the executive branch of government.

This has implications at two levels. First, the NPM-advocates stressed the need to strengthen the position of the political executive. The council and other similar representative bodies should not indulge in 'overregulation and micromanagement' (Kettl 1995). In local politics and government in several countries this has resulted in pleas for the introduction of the strong, directly elected mayor (Denters and Rose 2005). Second, NPM-adherents also have propagated the doctrine 'let managers manage' as a key element in the NPM reform program (Kettl 1997). This principle implies that politicians should allow more discretion to the civil service and its managers. According to many observers, the NPM-movement has affected European local governments (e.g. John 2001; Denters and Rose 2005). For instance, in Germany, local government has undergone significant changes since the early 1990's adopting strong-mayor system with elected mayors in South German cities (Wolmann 2005). In this setting, the mayor is directly elected and chairs the municipal assembly and heads the administration.

In France, mayors are both an elected authority - by municipal councils - and a representative of the state. Following the decentralization reinforcement (after 1981), the scope of local initiatives dramatically increased reversing the role of mayor from the state's agent to representative of city in the state (Newman \&Thornley 1996). Hence, mayors are powerful positions and in fact mayoralty stands at the centre of local governance. Evidently such model likely to have left visible marks on the relations between the various actors in European town halls.

One of the advantages of the strong mayor system is the strong leadership with centralized responsibility. This in turn can mean more efficient and effective policy 
implementation as a strong mayor is able to hire and fire department heads and is largely responsible for the municipality's budget decisions.

The model ensures division of labor. The Council's job is to take a long-range view of governmental needs. The Council acts as the deliberative arm of the government, balancing the interests of residents against the resources at the government's disposal, and then thoughtfully promulgating its budget, ordinances and policies. The mayor is empowered to speak on behalf of the government, lobby for its causes, and set its tone and direction.

On the other hand some feel that the focused responsibility may be too much for a single person, and this can be seen as a disadvantage. Also, because a mayor may not be a professional administrator there are concerns of inefficiency or that the concentrated power could lead to appointments based on political reasons rather than experience or abilities. In addition there is a large volume of tasks for a mayor; the mayor may not be also a professional manager (specialist).

\section{The Commission Model}

The commission form of city government, also known as the Galveston Plan, was devised in Galveston in 1901 in USA (Chandler Davidson, 1984). In this form of urban management, major services and functions are headed by separate commissions. Voters elect a small governing commission, typically five or seven members, on an at-large basis. As a group, the commissioners constitute the legislative body of the city responsible for taxation, appropriations, ordinances, and other general functions. Individually, each commissioner is in charge of a specific aspect of municipal affairs, e.g., public works, finance, or public safety. A commissioner can oversee public works. Another commissioner sees that the city has an adequate supply of clean water and that the streets are kept in good repair. A third commissioner can oversee the city's finances, including tax collection. The fourth commissioner might supervise the public welfare department, which helps the city's disadvantaged citizens. Still another commissioner might run the health department, which supervises hospitals, clinics, and health inspectors in the city.

This model of city government has certain disadvantages. For example, voters may find it difficult to elect officials who know how to run a department of the city's government. In addition, commissioners sometimes disagree about who should manage activities and budgets that fall under the jurisdiction of different departments.

One of the commissioners is designated chairman or mayor, but his function is principally one of presiding at meetings and serving in ceremonial capacities. Thus the commission plan blends legislative and executive functions in the same body blurring checks and balances. 


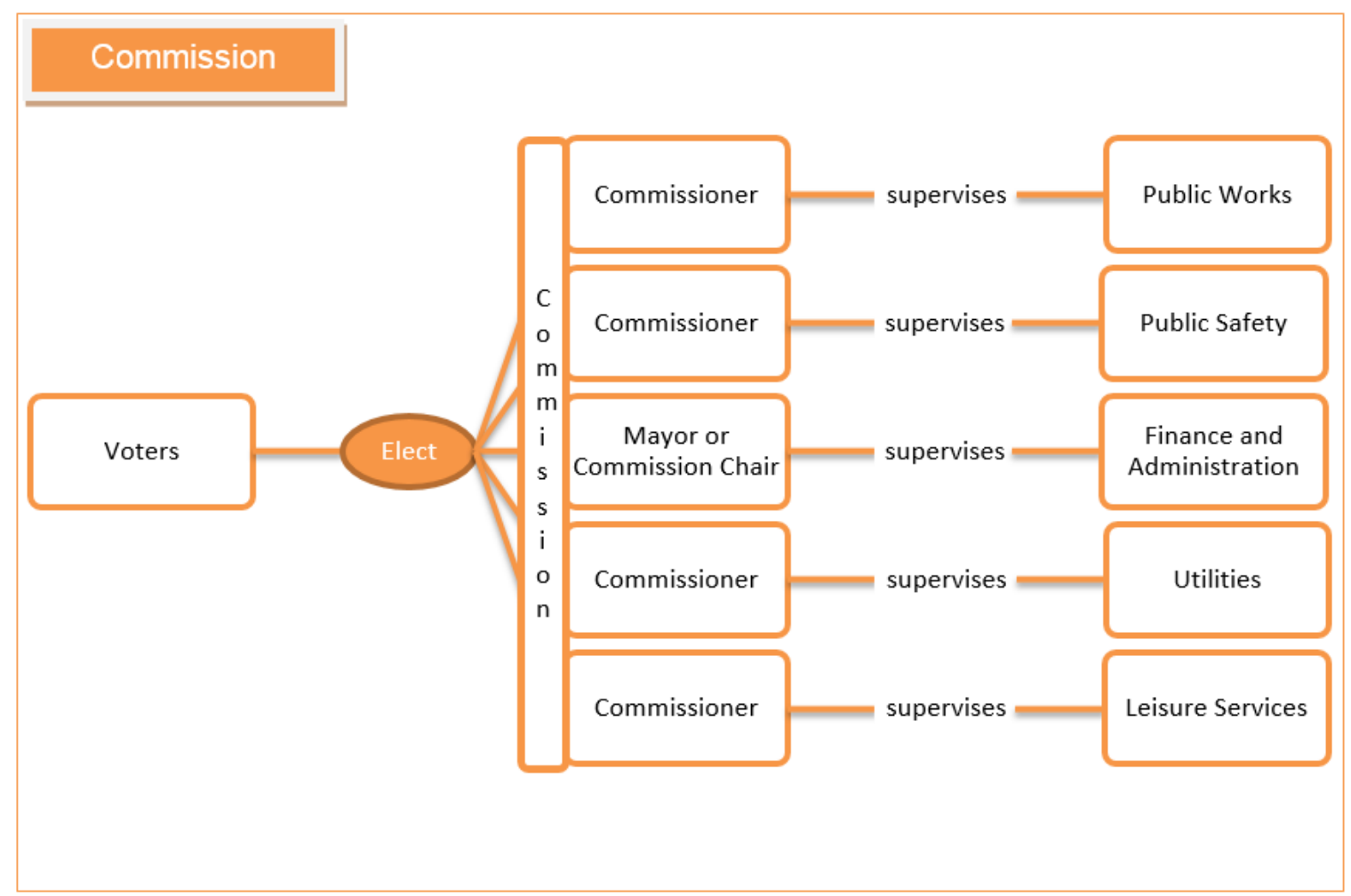

Figure 2 The structure of commission model (ICMA)

\section{The Council Manager Model}

Citing the short comings of the preceding models the reformers set out to separate politics from administration and create a form of government based on "neutral competence.” Among the reforms, the council-manager provided for an elected city council with a professionally trained manager to administer various municipal departments (De Visser, J. (2001). Such is the case in Australia, Ireland, and the U.S. The council-manager form is the system of local government that combines the strong political leadership of elected officials in the form of a council or other governing body, with the strong managerial experience of an appointed local government manager. The form establishes a representative system where all power is concentrated in the elected council and where the council hires a professionally trained manager to oversee the delivery of public services.

Freed from political constraints and daily pressures of having to pacify various political constituencies prevalent in the other models, the professional manager could ideally make decisions based on economy and efficiency. So the council- manager form of government is based on the theory that the business of local government is to provide basic administrative services and should not therefore, be political. The council is responsible for the formulation of municipal legislation and policies and approving the budget. It does not involve itself in the day-to-day affairs of the municipality. This task is left to the manager who in turn recruits and appoints qualified staff in the different departments of his/her administration (National Civic League, 1996).

To ensure objectivity and professionalism of the manager, cities have to advertise job openings and get applications from within and outside the community. The following picture depicts the form of council manager mode. 


\section{Council-Manager Form of Government}

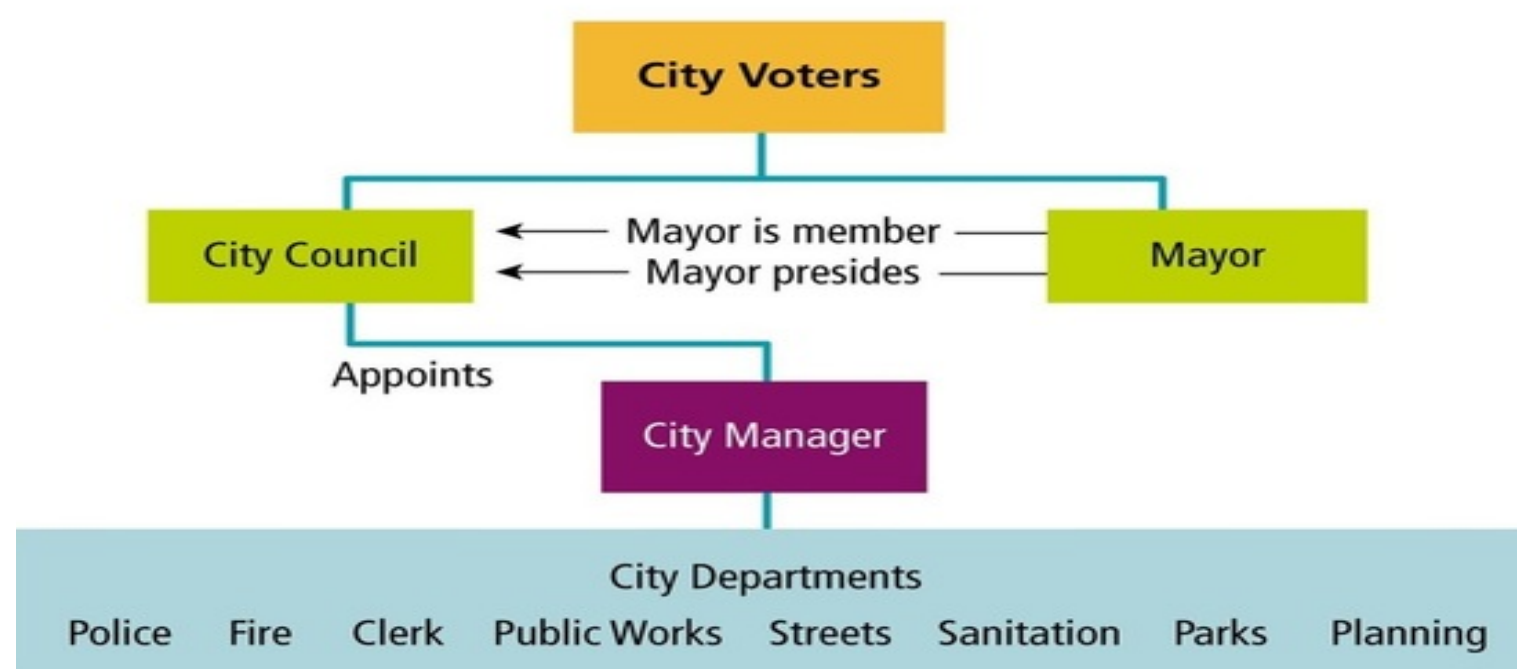

Figure 3 The structure of council-manager model (ICMA)

The figure depicts that the manager appoints department heads, including police, fire, public works, planning, parks and recreation and other as the need prevails. The department heads, supervised by the city manager, oversee the delivery of city services. The council plays no formal part in hiring, firing, or disciplining department heads (Kweit and Kweit, 1999). The manager is also responsible for the budget which plays a crucial role in shaping city services, although the council must approve the manager's budget proposals.

The mayor's role and appointment in the council-manager system can be quite varied (De Visser, J. (2001).Some municipalities appoint mayors from the pool of council members by a vote of the council. Others elect their mayors directly with votes from the general population. The actual duties of a mayor can also vary. Some mayors vote as normal members of the councils. Other mayors are only given vote with only the authority to preside at meetings and in order to break a tie in the voting process. One can infer from the model that it aims at separating the administrative roles from the legislative roles so that council can concentrate on policy making. Some proponents of this form claim that using a manager leads to more fiscal responsibility and cost cutting - one of the goals of this system is to manage a municipality more like a business (C Richard Tindal and Susan, 1995).

\section{Urban councils and executive branches in Ethiopia}

This section aims at analyzing the council-executive styles in Ethiopia urban centres .It is often best to begin with a review of the urban proclamations, city charters and code of ordinances in order to identify the nature of urban government structure because these documents state the role of elected officials, top executives and the staff who involve in day-to-day operation and management. Most of the major legislation governing municipalities in Ethiopia dates back to the Imperial regime. The Imperial Administration 
issued legislations governing municipalities since early 1940s. The first of this kind was Decree No.1 of 1942 which allowed the creation of municipalities with appointed councils under the control of the Ministry of the Interior (Sisay Ashenafi, 1996). Further elaboration of municipal functions and central control mechanisms was provided in Proclamation No.74 of 1945.

Part 73 of the legislation states the nature of a council which was composed of representatives of various ministries and seven residents elected yearly amongst property owners and principal merchants. The council had the authority to deliberate and decide on matters dealing with the development of the town and the welfare of its inhabitants as well as fixing municipal taxes and rates (Sisay, 1996). On the other hand, part 71 of the same decree provided for the status of chief executives of municipalities. The chief executives were named Kantiba(mayor) or Lord Mayor for Addis Ababa and Gondar municipalities, which were designated as municipalities. Addis Ababa (the capital city) and Gonder (due to its great historical and religious importance) were classified as municipalities (cities) and were made to be directed by appointed mayors. It was also stated that the Emperor would appoint mayors upon the recommendation of the Ministry of Interior. All other nonchartered municipalities were to be headed by Town Officers. The town officers of towns and cities were made to receive instructions from Governor Generals of their respective provinces.

A particularly major reform at the time was taken with the issuance of General Notice No. 172 of 1954 that recognized the status of Addis Ababa as an autonomous chartered city. The charter gave Addis Ababa its own council with legislative powers on matters of policy. The "Kantiba" or Lord Mayor enjoyed the status of a governor general of a province and was to act as the chief executive officer and preside over the council. Furthermore, the city was given special powers, including the authority to issue bonds and to raise capital from domestic and external sources. Addis Ababa was an exception in this regard because no other municipality was provided with this legal authority. Indeed, all other municipalities of the empire were subject to strict control and supervision by the Ministry of Interior and the governor-generals of their respective provinces.

Municipal elections were not entirely democratic during the Imperial era. Among other things, the qualifications for candidacy were based on ownership of property. The automatic inclusion of representatives from seven ministries in the municipal council was also a requirement to ensure the influence of the central government. Moreover, the municipality's directorate within the Ministry of Interior was made responsible for oversight the proper functioning of municipalities as well as issuing the necessary procedures that govern their operations. Following the overthrow of the monarchy in 1974, the military regime issued a series of legislations, which affected the functioning and institutional set-up of municipalities and towns in Ethiopia. The first landmark legislation was proclamation No.47 of 1975 that provided for the nationalization of urban land and extra urban houses. The proclamation designated a new Ministry of Works and Housing (later successively known as the Ministry of Housing and Urban Development and Ministry of Works and Urban Development) and transferred all the functions and authority over municipal administration from the traditional Ministry of Interior to this new institution.

The regime created various forms of Urban Dwellers' Associations (UDAs) in urban centres, peasant associations (PAs) and service co-operatives in rural areas to 
undertake development functions and deliver services to the people. Organizationally, municipalities were hierarchically organized into Central UDAs, Kefitegnas ('Higher' UDAs) and neighbourhood associations or Kebele associations depending upon the size of the population. To further consolidate the process of municipal reorganization, the Derg regime (military government) issued the Urban Dwellers Association Consolidation and Municipalities Proclamation No. 104 of 1976. This law provided for Addis Ababa to be headed by a mayor and all other urban centres by town officers. It also provided for the organization of all urban dwellers into co-operative societies of Kebele, Higher and Central UDAs by defining the roles of these institutions in urban administration. Accordingly, every town was to be administered by a council composed of elected members and two representatives from the Ministry of Urban Development and Housing. The single most important requirement for election was laid down as acceptance of the then Ethiopian National Democratic Revolutionary Programme which was the ideological guide of the regime.

Although municipal functions that were laid down in preceding legislation were listed as the powers and duties of central UDAs, those powers and duties common to UDAs and those specifically entrusted to Kebele and Higher UDAs were by and large political, and could be categorized as non-municipal functions by their very nature.

Municipal council elections were periodically held and the then Ministry of Housing and Urban Development was to appoint a chairman, a deputy and a secretary from among those elected. The three officers worked on a full-time basis but the council was supposed to carry out both legislative and executive functions. The major criteria for elections and appointment were essentially political and ideological, that is, ruling party membership and support for the government.

\section{Urban Centres in the Current Setting}

Based on the 2007 census, the total number of urban centres officially recognized by the CSA was 973 and the urban share of the total population is $17 \%$. According to the Ethiopian urban planning law, an urban centre is a locality with a minimum population size of 2000 inhabitants, 50\% of whom are engaged in non-agricultural activities. Despite long time history of urban settlement in Ethiopia, the structure and styles of the urban government emerged recently. This is witnessed only in the proclamations issued in late 1990s and early 2000s following overall nationwide reform initiatives. When the current government came to power in 1991, it proclaimed a decentralized form of government and developed a constitution that established a Federal Democratic Republic, consisting of: nine Regional States, the special administrative region of Dire Dawa and the federal capital Addis Ababa. Hence, since 2000 national decentralisation policies have formed part of a large scale reform of government resulting in the creation of institutional and legal frameworks for urban local government authorities. The objective has been to create and strengthen urban local government that will ensure public participation, democratization; and enhance decentralized service delivery through institutional reforms, capacity building, systems development and training.

The constitutions of both the Federal Government and the Regional States express the right for self-rule and administration at all levels of government. As Ethiopia pursues federal type of government where regional states enjoy autonomy, individual regions have made series of legal and institutional reforms to improve municipal service delivery, 
infrastructure provision and governance. To this effect, the various regions enacted proclamations in different periods, the Amhara National Regional State enacted such legislations in 2000 (Proc. No.43/2000), followed by the Southern Nations, Nationalities and Peoples Region (Proc. No.51/2002), Oromia Region (Proclamation No. No.4/1993,Tigrai Regional State (proclamation No.21/1997).

The Oromia Regional state enacted its first legislation even before the promulgation of the Federal Constitution. The municipal authorities and Rural Kebels (neighborhoods) Establishment Proclamation No.4/1993 was issued based on Art 29(b) of the Transitional Period Charter, which guaranteed the right of nations, nationalities to administer their own affairs within their own territory and Art 38 of the National/regional Self-Governments establishment Proclamation No.7/1992.

According to the proclamation, a municipality has the following organs: A municipal council or municipal committee depending on the size of the municipality; An executive committee; Services and development affairs.

The Amhara region enacted two Regulations in the 90s. These are Regulation No.3/1995 and the proclamation of 1997. The former was issued to establish special zone of Bahirdar City and to define its duties and responsibilities whereas the latter was enacted to reorganize urban woredas (districts) and their duties and power. According to the proclamation of 1997,urban woredas have councils which perform both rural and urban functions. Functions that pertain to urban centres are stipulated in Articles 6.1-6.4. this proclamation was amended by proclamation No. 43/2000 which was later revised by proclamation No.91/2003. Proclamation No.91/2003was issued to provide for the establishment and organization of urban centers of the Amhara National Region and definition of their powers and duties. On the other hand, the Tigrai regional state enacted the Tigrai Region's Municipalities' Administration Proclamation No.21/1997 with the view to addressing the municipal problems of its cities. Art.3 of the proclamation vests municipal status for selected urban Centers in the region. Among the principal organs provided in the proclamation are: The council; The executive committee; The administrative section; Subordinate committees. Art.9 states that the council shall consist of members directly elected by the people and Art.12(2) provides that the executive committee is accountable to the council.

\section{The City of Addis Ababa}

The Addis Ababa City Charter No.361/2003 defines the powers and functions of the city and identifies its principal organs. The principal organs include the council, the executive committee and the governor (mayor). The executive committee assumes an executive power that is more important than the governor. Among other things, the committee ensures the proper implementation of policies and laws issued by the federal Government and the city council, directs, coordinates and supervises the activities of organs and institutions accountable to the office of the city government. It also prepares and submits development plans and annual budget and implements the same upon approval. This indicates that the city has strong executive committee/council and not strong governor. However, the governor remains an important organ by virtue of the fact that he chairs the executive committee as well as the council.

Although the regional governments have more autonomy to reshape their urban centers, due to lack of urban management experience, they adopted more or less similar 
patterns of urban government styles. The dominant style is council-mayor form of government and this is evident from the regional government experiences (example, Amhara Region City Administration Proclamation No.43/2000 and Tigray Proclamation No.107/2006). As indicated in the literature the Council-Mayor system is a governance arrangement whereby the City Council makes policies and major decisions and the executive power vested in the mayor and the Mayor's Committee depending on the choice of strong or weak mayor style.

In the Ethiopian urban centres which adopted the Council-Mayor system of governance, the city governments are mostly composed of the following organs (Bahru Detti, 2013): The City Council; The Mayor; The Mayor's Committee; The City Court.

The following section is dedicated to the discussion of the nature and roles of the first three urban government organs stated above.

\section{The City Council}

The city council, elected every five years, is accountable to the constituency, and, in the case of Addis Ababa and Dire Dawa that have chartered city status promulgated by federal proclamations, their accountability extends to the Federal Government too. The size of the population of each city determines the size of membership of the city council and determined by the Regional Executive Council. In all cities, the mayor is elected from council members to perform executive functions. Members of the city cabinet (mayor's committee) who are in charge of city departments are nominated by the mayor and approved by the City Council.

\section{Powers and Responsibilities of the Council}

The council is responsible to make major local ordinances and laws; approve basic organizational and operational documents and ensure their enforcement. To that end it follows up and supervises the policy implementation process; elect the mayor and, if deemed necessary, a vice mayor from among its members and determine the terms of their services. Based on the proposal of the mayor, it approves the size and the members of the Mayor's Committee. In addition the council elects the Speaker and, if deemed necessary, deputy speaker of the council from among its members. It also appoints the president and the judges of the city court and passes ordinances which shall take effect upon their publication in the local Gazette. The council also introduces, adjusts and ensures the collection of taxes and service charges according to law. It initiates, oversees the preparation of and approves the city plan; ensures its implementation in consultation with the public. It approves the annual work program and budget of the city and ensures the proper execution thereof. The Council convenes regular meetings every two months.

The Mayor

The Mayor is elected by the Council from among its members on the recommendation of the political party that constitute a majority seat in the city council. The mayor is accountable to the City Council and the Governor of Regional State depending on the status of the city. There are also instances where mayors are appointed by zonal or regional governments in which case the mayor can be brought from places other than the city, which conflicts with urban democracy.

The Duties and Responsibilities of the Mayor 
The mayor serves as the chief executive officer of the city. The mayor has the responsibility to execute and follow up the implementation of laws, policies and guidelines issued and decisions made by the city council. He/she initiates and proposes policies to the council and ensure their implementation upon approval. As the chief executive officer he/she serves as the head and ambassador of the city and represents the city in its official and ceremonial dealings with others. In addition the Mayor chairs the mayor's committee. In consultation with the concerned bodies the mayor organizes public forums where city work programmes, budget, performance, financial reports and other matters would be presented and the views of the public heard.

\section{The Mayor's Committee}

The membership of the mayor's committee consists of council and non-council members. The mayor's committee is accountable to the mayor and to the council. A minimum of four standing committees, each with membership size of 7-13, are established.

\section{Powers and Functions of the Mayor Committee}

The mayor's committee has the following responsibilities:

1) The Mayor's Committee ensures the implementation of laws, decisions and standards adopted by the State Government and City Council.

2) The Mayor's Committee draws up annual city budget and, when approved by the City Council, it shall implement it.

3) The Mayor's Committee formulates social, economic and development policies, strategies, programs and; when adopted by the City Council, it shall implement

\section{The introduction of council-mayor model}

The regional states later amended previous proclamations in order to reorganize their urban centres and their roles. Amhara, SNNPR, Oromia and Tigrai regions issued (Proc. No.91/2003), (Proc. No.103/2006), (Proc. No.116/2003) and (Proc. No.107/2006), respectively. Accordingly, the council-mayor model in most urban centers which was dominant in Ethiopia during the early periods of the reform has been modified. Examinations of urban government structure indicate that currently council-mayor forms of government are less distinct than they once were. This is due, in part, to the common practices of incorporating structural features from other forms into the model. It seems that the introduction of council-manager model is attributed to local responses to perceived distinct realities of regional states in relatively larger towns.

In those urban centres which adopted this model, city managers are responsible for municipal services and accountable to the mayor. The services that are under the purview of the city manager include preparation of detail plans, land development and administration, construction and management of city roads, sewerage and drainage lines, development and management of public parks and recreational areas, urban greenery and beautification, waste collection and disposal, sanitation and street cleaning, provision of land and building permits, control of pollution, abattoir services, civil status record operations, water supply, street lighting and fire protection. The following section shows how various regional states and Addis Ababa City Government introduced the councilmanager model in their legislations.

Amhara National Regional State 
The Revised Proclamation No.91/2003 was issued to provide for the establishment and organization of urban centers of the Amhara National Region and for the definition of their powers and duties. Unlike the previous one, the revised legislation has categorized cities/towns within the region in to three to define their administrative status, organization and management. These are City administration towns, municipal towns and emerging towns. In each of these categories, there is a manager in charge of urban services.

The proclamation introduced a variant of council-manager model to enable professional service provision in the cities. According to the Proclamation, the manager is appointed by the mayor based on professional competence and experience. In case of loss of confidence, the mayor removes the manager. As a chief of urban services, the manager remains accountable to the mayor and has the following powers and duties, among others (Article 22 (4):

a) Employing, managing, suspending or dismissing subordinate officials under him,

b) Attending council's or mayor's committee meetings; takes part in their deliberation without having a voting right,

c) proper implementation of laws of federal and regional governments, policies and directives that the city administration issues as well as the decisions that it makes each time,

d) Submitting periodic work plan, performance and financial activity reports to the mayor and to the city council,

e) Presenting other reports up on the request of the council or the mayor's committee,

f) Advising the city council and the mayor's committee to have complete information on financial conditions and future needs of the city administration,

g) Conducting a study and submitting the same to the mayor on the circumstances that improve the revenues of the city and give security and insurances to the city residents as well as on the condition of the provision of integrated service,

h) Causing that good and friendly ties to be maintained with the community so as to engender healthy communication and supportive leadership,

i) Addressing the petitions of the resident population and acts thereon without delay,

j) Nominating the deputy for mayor's approval, when necessary,

k) Presenting to the mayor's committee via the mayor the proposal of internal departments and organizations necessary for the city services together with the details of operation and implements the same upon approval

\section{Oromia Regional State}

As stated earlier Oromia is the pioneering region in introducing legislation for its urban centers since the Transitional Government. Later on, it had the revised Proclamation No. 26 of 1999. The functioning legislation at the moment was introduced in 2003 by Proclamation No. 65/2003. Like the previous legislation, the current proclamation has also categorized/graded cities/towns in to four main parts. These are:

a) Grade one: cities/towns having greater than 90,000 residents,

b) Grade two: cities/towns having residents between 45,000 and 89,999,

c) Grade three: cities/towns having residents between 10,000 and 44,999,

d) Grade four: cities/towns having residents between 2000 and 9,999. 
The proclamation states the necessity of mentioning the grade of any urban center for conferring legal certificate. There also exists a manger for each level of urban centers in charge of the execution of municipal services. The manager is recruited by the mayor for defined period of time on the basis of his/her managerial and professional merit. His/her employment is contractual and he/she is accountable to the mayor. According to the Proclamation, the powers and functions of the manager include:

a) Leading and coordinating municipal services,

b) Preparing and developing service delivery standards, and performance indicators to the mayor, and ensure the performance of same up on approval,

c) Ensuring the implementation of council decisions as well as the regional government laws, policies and standards,

d) Establishing and chairing a management team constituting of organs of municipal service working under him/her,

e) Appoint heads of the organs of municipal services,

f) Recruiting, administering and dismissing human resource working in the municipal service in accordance with the law,

g) Proposing to the mayor the establishment of municipal service bodies and alternative service delivery mechanisms, and implement same up on approval,

h) Presenting periodic performance targets and directives to the mayor and implementing same up on approval,

i) Preparing and presenting to the mayor annual work program and budget of municipal services and implementing same up on approval by the city council,

j) Maintain transparent and open process to address the complaint of residents concerning municipal services and offer explanations to queries promptly,

k) Submit to the mayor periodic and annual work performance and financial reports.

Addis Ababa City Government

Addis Ababa city government was re-established by the 1997 Charter which was revised by Proclamation No. 361/2003. Under its Article (10), it has provided the organs of the city government at City, Sub-city and Kebele levels. It also states the election of the Mayor by the council from among its members having similar term of office with the council. The mayor is accountable both to the federal government and the council and he is the chief executive officer of the city and responsible for the normal transactions of the business of the city.

According to the Proclamation, the municipality is reorganized and mandated with many responsibilities in performing a range of activities. To this effect the city government is composed of a Council, Mayor, Manager, City Cabinet, City Judicial Organs., and Chief Auditor. The city has also council standing committees responsible for running seven sectors namely; finance\& economic affairs, capacity building, municipal services, justice and good governance, women, youth and social affairs, urban development and environmental protection, communication and cultural affairs.

Unlike the previous proclamations, the new proclamation provided and legally instituted the structures and functions of city management. Article (24) of the charter has instituted the city manager as the chief of the municipal service. The manger is hired as well as fired by the Mayor and remains accountable to the mayor for his functions. The city management was also instituted at Sub-city and Kebele levels. Each 10 Sub-cities has its own manger accountable to the city manager and the Sub-city Chief Executive of the 
respective sub-city and responsible to carry out functions provided under Article 37 (2) of the Charter, organize, and direct municipal service organs.

\section{The Role of the City Manager}

The City manager shall:

a) make recommendations, to the Mayor, for the establishment of municipal bodies

(b) nominate candidates for appointment, by the Mayor, as heads of municipal service bodies; direct; in accordance with law, the operations of such heads and effect their discharge;

(c) hire, under a contract of employment for a definite period, competent professionals as sub-City Managers as well as administer and dis $\neg$ charge same; receive, examine and decide upon annual and, where necessary, periodic reports from sub-City Managers;

(d) submit to the Mayor action plans and budget proposals concerning city-wide and inter-sub- $\neg$ City municipal services and implement same upon approval;

(e) develop and submit to the Mayor service delivery indicators and guidelines and im $\neg$ plement same upon endorsement thereof;

(f) ensure the delivery of efficient, transparent and equitable municipal services;

(g) execute decisions concerning municipal services;

(h) initiate and submit to the Mayor policy proposals and draft laws concerning municipal services;

(i) recommend, to the Mayor, a candidate for employment as Deputy City Manager and hire same upon approval;

(j) submit work performance reports to the Mayor;

(k) receive and handle as well as respond, reasonably fast, to the pleas of residents concerning municipal services;

(l) constitute and direct a management committee consisting of the heads of organs subordinated to him,

(m) perform other functions assigned to him by the Mayor.

In the current Ethiopian urban centres which adopted the city management model, the main job of the managers is to implement municipal polices and provide professional and efficient services to residents. He is responsible for day-to-day activities of the cities. The relation between the mayors and the managers can be explained as superiorsubordinate relationship because city legislations oblige the manager to answer to the mayors. The managers propose ways and means on how to provide services to the residents. It is up to the mayors to accept these proposals. For proposals that involve technical issues, the managers may have a professional discretion to explain and get them approved. In practice, both need to work together closely because of the fact that municipal functions for which the managers are responsible take much of the resources and energy of the city administration and they constitute basic urban services which are needed by the residents on the daily basis.

But the way council-manager model functions in Ethiopia differs from the nature of council-manager style stated in the literature. In both Addis Ababa and regional cities, no vacancies are announced to recruit managers on competitive basis. In the literature it was indicated that mangers have to be recruited by widely published vacancy announcements with the criteria of professional fitness, experience and competence. Political neutrality is also important to avoid partisan behavior in urban management. A 
municipality operating under the council-manager form of government has to be clearly chosen to fundamentally alter its form of government in order to instill professional management consideration and non-partisan basis in daily operations.

However, under the current political environment in Ethiopia, neutrality of city managers is questionable. There is no also direct relationship between the manager and the council. In the literature, the council hires the manger and the extension of managers' contract depends on the approval of the council. The council has the power to fire the manager when it believes the manager is not acting professionally. The manager is under the council's surveillance to ensure professional urban service delivery. Hence, the manager should possess a direct reporting relationship with the city council. This allows the manager to provide his or her professional advice to the full governing body rather than to a single political official.

\section{Conclusion}

For a long time, various typologies of local self-government systems have been proposed. They are based on theory and empirical evidence and concern the division of power in local communities, i.e., the relationships between the local council, the mayor, and the executive officials. As indicated in this study, there is no one best way of structuring local government. Nor are there a multitude of models available to guide the organization of local governance institutions. A survey of limited literature of local government organizations reveals that only three basic models (with some possible adaptations or variations on each one) have evolved over time. Circumstances (history of local government development, socio-demographic, cultural and political characteristics) dictate, to a large extent, which model any one of the jurisdictions follows. One of the most important aspects of effective government is defining, understanding, and accepting the appropriate roles of elected and appointed officials. In local governments today, there are three primary forms of government, namely the council-manager, mayor-council, and commission forms of government.

As indicated earlier, the idea and practice of urban management in Ethiopia began early 1940s when proclamation No.1/1942 was promulgated by the Imperial government. Similar provisions were also issued in the Derg(socialist) regime to redefine the roles and functions of the urban centers. In Both regimes only traditional urban functions were identified and assigned to the urban centres and the roles of the council and the mayor were crudely stated. The type of council-executive relationships, the power that one branch has over the other, the relation between the department heads and the mayor etc.were not identified. In both regimes urban governance and management was highly centralized where the higher tiers of government including the central government exercised strict control over the urban centres. Thus, political roles were more pronounced than managerial roles of the urban centres. The Imperial government issued the first and subsequent urban related proclamations after coming back from exile due to Italian aggression. Hence, the proclamations mainly aimed at consolidating the power of the emperor. In Dergregime it was clear that the single most important requirement for election on to the council was the acceptance of the then Ethiopian National Democratic Revolutionary Programme which was the guiding ideological doctrine of the regime. Due to this, politics and management were not demarcated and the urban council and executives were all politicians. It was stated 
that one of the duties of the leading functions of the municipalities was to protect the revolution and its gains.

In both regimes, municipal governance had a tradition of centralist government structures. Municipal structures were established in some cities, but the mayors were centrally appointed and municipalities were treated as branches of central government. Despite the adoption of council manager model in some urban centres in various regions since the current government came to power, strict adherence to the principles of councilmanager model is not warranted. In the review of literature, it was indicated that the manager is politically neutral, professional and hence the selection is based on open vacancy announcements. As the guiding principle is to separate politics from operation, the sole criteria for the recruitment is competence and neutrality. As the result the employment tenure is contractual, that is dictated by manager's efficiency, effectiveness and fairness in the discharge of responsibilities. In Ethiopia there is no evidence that the managers are selected based on these criteria.

Are the urban governments afraid of leaving the urban affairs to the outsider? Is patronage still preferred in the politico-managerial interface? These questions need further study.

\section{References}

1. Ammons, David N. and Charldean Newell (1989). City Executives: Leadership Roles, Work Characteristics, and Time Management State University of New York Press,

2. $\quad$ Anderson, Andrew (2007), Should the Mayoral System Be Scrapped? You Get to Decide, Doncaster Free Presshttp://www.doncasterfreepress.co.uk/ViewArticle.aspx?SectionID. Accessed on January 10, 2018. 3. Arthur Watson Bromage (1957), Introduction to Municipal Government And Administration. Publication: New York, Appleton-Century Crofts.

4. Bahiru Detti (2013), Urban Management Models in Ethiopia. Term Paper Presentation for the course Urban Local Governance and Management. Addis Ababa University

5. $\quad$ Bayisa Tesfaye (2013), An Assessment of Urban/Municipal Management in Ethiopia since 1942. Term PaperPresentation for the course Urban Local Governance and Management. Addis Ababa University.

6. C Collinge (1997), Political Power And Corporate Managerialism in Local Government: The Organization of Executive Functions. Centre for Urban and Regional Studies, The University of Birmingham, Edgbaston, Birmingham. Environment and Planning C: Government and Policy 1997, volume 15, 347 - 361 https://doi.org/10.1068/c150347

7. Choi, C.G., et.al. (2013), The Adoption and Abandonment of Council Manager Government. Public Administration Review 73(5): 727-36. https://doi.org/10.1111/puar.12097

8. Deno, Kevin T. and Stephen L. Mehay, (1987) Municipal Management Structure and Fiscal performance: Do City Managers Make A Difference?: Southern Economic Journal, January 1987. 53(3): 627-42. https://doi.org/10.2307/1058759

9. De Visser, J. (2001) Roles and Responsibilities of the Municipal Manager. Local Government Working Paper Series No. 1. Community Law Centre, http://hdl.handle.net/10566/4737

10. Gaynor Paradza Lebogang et.al (2010), Assessing the role of councilors in service delivery at local government level in South Africa: Research Report No 125

11. Hayes, K., and Chang, S. (1990). The Relative Efficiency of City Manager and Mayor-Council Forms of Government. South Economic Journal 57: 167-77. https://doi.org/10.2307/1060487

12. International City Management Association. Municipal Year Book. Washington, D.C., 1988.

13. International City/County Management Association (ICM). 1999. The municipal yearbook. Washington, D.C.: ICMA.

14. Jacobowitz and Gubits, Llp (2006) (2006), Alternate Forms of City Government. Walden, New York 
15. John P. Pelissero Loyola, Timothy B. Krebs (1997), City Council Legislative Committees and Policy-making in Large United States Cities. Loyola University ChicagoLoyola commons.Political Science: Faculty Publications.

16. Korey Dickens, Brandon Fris - Brian Wallace (2012), Handbook for Georgiye Mayors and Council Members, Georgia Municipal Association, Georgia: Published in Cooperation with the Carl Vinson Institute of Government - University of Georgia.

17. Magre, F. J. and Bertrana, H. X. (2005), Municipal Presidentialism and Democratic Consolidation in Spain. In Transforming Local Political Leadership, Edited By: Berg, R. And Rao, N.73-84. Houndmills: Palgrave.Macmillan.

18. Mouritzen, Poul Erik, James H. Svara (2002) Leadership at the Apex; Politicians and Administrators in Western Local Governments. Pittsburgh: University of Pittsburgh Press

19. Morgan, David R., and Pelissero, J.(1980), Urban Structure: Does Political Structure Matter? American Political Science Review 74(4): 999-1006, https://doi.org/10.2307/1954319

20. National Civic League (1996), Model City Charter. A Publication of the National Civic League. Denver, Colorado, USA

21. Nelson, Kimberly L., and Svara, James H. (2012), Forms of Government Still Matters: Fostering Innovation in U.S. Municipal Governments. American Review of Public Administration 42(3): $257-81$. https://doi.org/10.1177/0275074011399898

22. Newman, P. \&Thornley, A. (1996). Urban Planning in Europe: International Competition, National Systems, and Planning Projects. New York: Routledge. Ridley High School, Folsom, Pennsylvania Paperback (1959) Yearbook May 1, 1959

23. Samuel Humes and Eileen Martin. (Mouton, (1969), The Structure of Local Government. Changing Patterns of Local Government. American Political Science Association 1971, 675.

24. ShewayeTesfaye (2001), The Challenges Of Urban Management in Ethiopia (With Reference to The Amhara Municipal Reform) Workshop on the Role of Urbanization in Socio Economic Development Process, December 17- 18, 2001,Nazareth, Ethiopia.

25. SisayAshenafiet.al (1996) Report of The Reconnaissance Mission on the Approaches and Problems of Urban Management and on the Legal and Institutional Framework of Municipalities, Urban Development Support Services, Ministry of Works and Urban Development, Addis Ababa.

26. Stephen Coate and Brian Knight (2011), Government Form and Public Spending: Theory and Evidence from US Municipalities. American Economic Journal: Economic Policy Vol. 3, No. 3 (August 2011), pp. 82-112 American Economic Association, DOI: 10.1257/pol.3.3.82

27. Svara, James H., (1987), Mayoral Leadership in Council-Manager Cities: Preconditions versus Preconceptions. Journal of Politics. https://doi.org/10.2307/2131141

28. Thornhill, C. (2005) The political/ administrative interface: time for reconsideration. Journal of Public Administration Conference Proceedings: 176-185. https://hdl.handle.net/10520/EJC51217

29. Wheeland, Craig M.(2000), City Management in the 1990s: Responsibilities, Roles, and Practices. Administration \& Society 32,: 255-281. https://doi.org/10.1177/00953990022019425

30. Wollmann, H. (2005) The directly elected executive mayor in German local government. In: Berg, R. \& Rao, N. (eds) Transforming Local Political Leadership, pp.29-41. Houndmills: Palgrave MacMillan. Proclamations

31. Imperial Government of Ethiopia (1942), Decree Number 1/1942: Administrative Regulations (NagaritGazetaNumber 6, 1942).Addis Ababa.

32. Imperial Government of Ethiopia (1945), Proclamation number 74 of 1945: provides for the control of municipalities and townships.Addis Ababa.

33. Imperial Government of Ethiopia (1954), General Notice Number 172/ 1954: Charter of the City Of Addis Ababa.Addis Ababa.

34. PDRE (1975), Proclamation number 47/ 1975: Government Ownership of Urban Land and Extra Houses Proclamation.Addis Ababa.

35. PDRE(1976), Proclamation number 104/1976: urban Dwellers Association.Addis Ababa.

36. PDRPE(1981),Proclamation number 206 of 1981: Urban Dwellers Association and Urban Administration Proclamation.Addis Ababa.

37. Oromia Regional State (2003), Proclamation Number 65/ 2003: Revised Oromia National Regional state Urban Administration.Addis Ababa. 
38. Amhara Regional State. (2003). Proclamation No.91/2003: Revised Proclamation for the Establishment, Organization and Definition of Powers and Duties of Urban Centres, Bahir Dar

39. AACG (2003), Proclamation number 361/2003: Addis Ababa City Government Revised Charter.Addis Ababa.

40. AACG (2009), Proclamation number 15/2009: Provides The Re Establishment of Addis Ababa City Government Executive And Municipal Services Organs.Addis Ababa.

41. FDRE. (2003). Proclamation No. 361/2003, the Revised Charter of Addis Ababa City Government, Federal Negarit Gazeta, Addis Ababa. FDRE. (2004). Proclamation No. 416/2004, the Revised Charter of Dire Dawa City Government, Federal Negarit Gazeta, Addis Ababa.

42. Oromiya Regional State (2006) Proclamation Number 116/2006 Revised Proclamation for Cities Establishment.Addis Ababa.

43. MUDHCo. (2014a). The Revised Urban Developmental Good Governance Capacity Building: Framework and Implementation Strategies (2006 E.C. in Amharic), Addis Ababa.

44. SNNPRS (2006) Proclamation Number 103/2006: Revised Proclamation for Cities Establishment.

45. Gambela Regional State. (2008). Proclamation No.73/2008: Revised Proclamation for Cities Establishment, Gambela.Hawassa

46. Somali Regional State (2011) Proclamation Number 90/2011 Revised Proclamation for Cities Establishment. Jigjjiga

47. Tigray regional state (2006) Proclamation Number 107/2006 Revised Proclamation for Cities Establishment Mekelle.Mekele

48. FDRE. (1995). Constitution of the Federal Democratic Republic of Ethiopia, Federal Negarit Gazeta, Addis Ababa. Creative Commons Attribution - Non Commercial - No Derivatives 4.0 International License. 